\title{
NOTAS SOBRE LA DENOMINADA “RESPONSABILIDAD” POR ACTO LÍCITO EN EL DERECHO CIVIL. RECONOCIENDO A LAS COMPENSACIONES POR SACRIFICIO*
}

Notes on "Liability" for a Legal Act in Civil Law. Recognizing the Compensations for Sacrifice

\author{
CARLOS CÉSPEDES MUÑOZ** \\ Universidad Católica de la Santísima Concepción
}

\begin{abstract}
RESUMEN
Se acostumbra a denominar como "responsabilidad por acto lícito" a un cúmulo de supuestos regulados por el ordenamiento jurídico que, legítimamente, permiten ocasionar daños, menoscabos o pérdidas al patrimonio de otro. A través del presente trabajo demostraremos que tales casos no constituyen hipótesis de responsabilidad civil alguna y que la consecuencia indemnizatoria prevista para ellos no lo es a título de resarcimiento por daño ilícito o antijurídico, sino que constituyen reparaciones dispuestas por el sistema para restituir los enriquecimientos obtenidos a costa de otros o para compensar el daño patrimonial sufrido por el afectado.
\end{abstract}

\section{PALABRAS CLAVE}

Responsabilidad, acto lícito, indemnización, restituciones, compensaciones por sacrificio

\section{ABSTRACT}

It is customary to denominate as "responsibility for a lawful act" a series of assumptions regulated by the legal system that, legitimately, allow damage, impairment or loss to the assets of another. Through this work, we will demonstrate that such cases do not constitute hypotheses of any civil liability and that the indemnity consequence foreseen for them is not by way of compensation for unlawful damage, but rather they are reparations ordered by the system to restore the enrichments obtained at the expense of others or to compensate the patrimonial damage suffered by the affected party.

\section{KEYWORDS}

Liability, Lawful Act, Compensation, Law of Restitutions, Compensations for Sacrifice

\section{Introducción}

Atendido que la denominada "responsabilidad por acto lícito" frecuentemente se nos presenta como una materia de interés académico ${ }^{1}$ y que, asimismo, tiene mucho más interés práctico que el que se piensa, parece conveniente reflexionar sobre esta institución, que es común al Derecho público y privado.

En el ámbito del Derecho público, se acostumbra a denominar así a las intervenciones emanadas de actos lícitos de la Administración que generan un daño, pérdida o menoscabo en el patrimonio de los particulares. Por ejemplo, la imposibilidad de cortar y explotar las araucarias

\footnotetext{
*Este trabajo se enmarca dentro del proyecto Fondecyt Iniciación №11180060, titulado “Las indemnizaciones por sacrificio en el Derecho civil chileno" y del proyecto DINREG 7/2018, denominado "La indemnización originada por los daños causados en estado de necesidad, financiado por la Dirección de Investigación de la Universidad Católica de la Santísima Concepción, de los cuales el autor es investigador responsable.

** Doctor en Derecho por la U. de Salamanca (España). Profesor de Derecho Civil de la U. Católica de la Santísima Concepción. Correo postal: Lincoyán 255, Concepción, Chile. Correo electrónico: ccespedes@ucsc.cl.

Se utilizarán las siguientes abreviaturas: Código Civil Chile (CC); Código de Comercio Chile (CCom); Código de Procedimiento Civil Chile (CPC); Código Orgánico de Tribunales Chile (COT); Código Penal Chile (CP).

${ }^{1}$ Por citar solo los más recientes, MONTT (2017) y HARRIS (2019).
} 
de propiedad de una sociedad forestal por la dictación de un Decreto Supremo que declara monumento natural a tal especie arbórea²; o la destrucción de productos cárnicos de origen extranjero adquiridas por una empresa de la industria de la alimentación, luego de que autoridades del país del cual se importaron advirtieran que animales de su origen presentaban los síntomas de la enfermedad de las vacas locas ${ }^{3}$. Es lo que se denomina también como "indemnizaciones de Derecho público" ${ }^{5}$, que comprende a todas aquellas concedidas a un particular por las intervenciones inferidas a su patrimonio por la Administración conforme a Derecho ${ }^{6}$ y que, según algunos, permite diferenciarla de la responsabilidad por acto ilícito ${ }^{7}$.

Este fenómeno, si bien poco explorado, no es ajeno al Derecho privado, motivando algunas referencias de la doctrina civil.

Corral, bajo el rótulo de "responsabilidad por hecho lícito", observa que en el afán de atender a la reparación del perjudicado, se podría prescindir del requisito de la antijuridicidad del hecho dañoso. Indica que de un hecho lícito, autorizado por la ley, se generaría responsabilidad si causa daño. Luego de mencionar que no son supuestos propios de responsabilidad civil, indica como ejemplos de ello a la indemnización expropiatoria, a la imposición de servidumbres bajo condición de pagar los perjuicios al propietario del predio sirviente y a la retractación tempestiva de la oferta ${ }^{8}$.

Barros, describiendo la "restitución en razón de cargas impuestas por actos lícitos", sostiene que existen actos que el derecho autoriza, incluso expresamente, pero que tienen por efecto imponer a otra persona una carga. Refiere que el hecho que la imposición de la carga sea lícita, no implica que asuma su costo el obligado a soportarla. Da como ejemplo de ellos a los daños causados en estado de necesidad, a algunas especies de ocupación, a las servidumbres legales y ciertas formas de accesión, manifestando que no se incurre propiamente en responsabilidad extracontractual. Agrega que, más allá de los casos regulados, puede asumirse un principio general de reconocer obligaciones restitutorias en casos de imposición privada de cargas excesivas pero lícitas ${ }^{9}$.

Aedo, por su parte, hace alusión a la "responsabilidad por conductas lícitas". Expresa que la ley atiende predominantemente al desvalor de resultado, no de la acción, no comportándose la antijuridicidad como factor de atribución. De ahí que la conducta puede ser lícita e irrogar perjuicios injustos. Da como ejemplos a la retractación tempestiva de la oferta y los daños causados en estado de necesidad ${ }^{10}$.

Pues bien, podemos percatarnos que los casos enumerados por los autores recién nombrados dan cuenta de ciertos daños, pérdidas o menoscabos patrimoniales originados en acciones o conductas ajustadas a Derecho, en que no existe transgresión a un deber jurídico alguno $^{11} \mathrm{y}$, no obstante, se concede una "indemnización". El objeto del presente trabajo es determinar si estos pueden catalogarse y tratarse efectivamente como supuestos de responsabilidad -como lo expresa su denominación- y, en la negativa, las implicancias de aquello. Las consecuencias prácticas las expondremos en un próximo artículo, dadas las restricciones editoriales en cuanto a la extensión de los trabajos.

\footnotetext{
${ }^{2}$ Corte Suprema, Rol № 16.743-1983, de 07 de agosto de 1984; Corte Suprema, Rol № 381-2004, de 30 de diciembre de 2004. Véase CÉSPEDES (2018a), p. 85.

${ }^{3}$ Corte Suprema, Rol № 9924-2010, de 20 de noviembre de 2012. Sobre el punto, CORDERO (2012). Véase CÉSPEDES (2018a), p. 85. ${ }^{4}$ Denominación utilizada por FLEINER (1933), pp. 233 y ss.; GARRIDO (1952), pp. 411 y ss.; FORSTHOFF (1958), pp. 426 y ss. Sobre el punto, MONTORY (2019), pp. 95 y ss.

${ }^{5}$ Sobre el concepto y su recepción en España, CÉSPEDES (2018a), pp. 80 y ss.

${ }^{6}$ FLEINER (1933), p. 235; GARRIDO (1952), p. 422; FORSTHOFF (1958), pp. 426 y ss.

7 GARRIDO (1988), p. 220; GONZÁLEZ (2016) pp. 177 y 178; CÉSPEDES (2016), p. 99. También en el sistema alemán se hace tal distinción, GARCÍA DE ENTERRÍA y FERNÁNDEZ (2017), pp. 391 y 392. En contra de la diferenciación, MIR (2002), p. 123.

${ }^{8}$ CORRAL (2013), p. 117.

${ }^{9}$ BARROS (2020), pp. 1043 y 1044; CÉSPEDES (2016), p. 308.

${ }^{10}$ AEDO (2006), pp. 266 y ss.

${ }^{11}$ BRIGUGLIO (1971), p. 174
} 


\section{¿Cabe hablar propiamente de "responsabilidad por hecho o conducta lícita"?}

En los supuestos que señala la doctrina comprendidos en esta denominación, junto con hablar de responsabilidad, se pone de relieve que ellos dan lugar a una indemnización. A través del análisis de aquellos, discerniremos si efectivamente dan lugar a una indemnización de daños propia de la responsabilidad civil, lo que implica reseñar los siguientes casos: 1) la indemnización por retractación tempestiva de la oferta; 2) la indemnización por imposición de servidumbres legales; 3) la indemnización por los daños causados en estado de necesidad; 4) las indemnizaciones vinculadas a situaciones de accesión; 5) la indemnización expropiatoria.

\section{La indemnización por retractación tempestiva de la oferta}

El inc. $1^{\circ}$ del art. 100 CCom dispone que "la retractación tempestiva impone al proponente la obligación de indemnizar los gastos que la persona a quien fue encaminada la propuesta hubiere hecho, y los daños y perjuicios que hubiere sufrido" ${ }^{12}$.

Se ha discutido sobre la naturaleza jurídica de esta consecuencia indemnizatoria. Claro Solar ${ }^{13}$ y León Hurtado ${ }^{14}$ sostienen que se trata de una obligación legal fundada en la equidad natural. Corral ${ }^{15}$ también comparte tal calificación, afirmando que no existe propiamente responsabilidad civil, ya que los casos de indemnización de daños ocasionados por conductas legalmente autorizadas son supuestos especiales en los que la ley condiciona la licitud de la actuación al pago de la indemnización.

Otros autores, en cambio, ven en esta norma un supuesto de responsabilidad. Rosende ${ }^{16}$ indica que es un supuesto de responsabilidad precontractual, en que la indemnización se impone por un sentido de equidad basada en la buena fe. Aedo ${ }^{17}$ menciona que es una hipótesis de responsabilidad extracontractual en que la indemnización se funda en la equidad, que viene a constituir un factor de atribución que reemplaza a la culpabilidad.

Entendemos que aquí no existe responsabilidad alguna, desde que la retratación de la oferta constituye una conducta permitida y autorizada por la ley: "el proponente puede arrepentirse en el tiempo medio entre el envío de la propuesta y la aceptación, salvo que al hacerla se hubiere comprometido a esperar contestación o a no disponer del objeto del contrato, sino después de desechada o de transcurrido un determinado plazo" (art. 99 inc. $1^{\circ}$ CCom). El hecho de ser una actuación permitida por el ordenamiento elimina la nota de reproche que existe tras el concepto de responsabilidad y, por tanto, impide que la califiquemos como un supuesto de responsabilidad civil, puesto que aquella se traduce en una desvalorización del comportamiento del sujeto, erigiéndose como mecanismo de restablecimiento o recomposición del orden normativo violado ${ }^{18}$.

Por lo anterior, compartimos la opinión de que estamos en presencia de una obligación legal ajena a toda idea de responsabilidad civil: la indemnización prevista en la norma no trae como causa un delito o cuasidelito civil (responsabilidad extracontractual) ni menos un incumplimiento contractual, pues no existe contrato. El hecho de ser una obligación legal se corrobora por la circunstancia que de no haber contemplado la ley la existencia de esta indemnización, no tendría derecho alguno a reclamarla el destinatario de la oferta retractada,

\footnotetext{
${ }^{12}$ Cabe señalar que en el Derecho comparado existen diversas soluciones para esta problemática. Un panorama de las mismas en RUIZ (2018), pp. 1357 y ss.

${ }^{13}$ CLARO (1979), p. 68.

${ }^{14}$ LEÓN (1991), p. 78.

${ }^{15}$ CORRAL (2013), p. 117.

${ }^{16}$ ROSENDE (1979), pp. 59 y ss.

${ }^{17}$ AEDO (2006), p. 267.

${ }^{18}$ KRAUSE (2015), pp. 54 y 55; LÓPEZ (2019), p. 20.
} 
ya que el oferente estaría amparado por la causal de justificación de ejercicio legítimo de un derecho ${ }^{19}$ (qui suo iure utitur nemimen laedit), que no otorga derecho a ningún resarcimiento" ${ }^{20}$.

Así también se ha sostenido por la doctrina italiana respecto de una norma del Codice similar a la chilena, que permite al oferente retractarse antes de la formación del consentimiento, pero a cambio de compensar al destinatario de la oferta por los gastos y pérdidas sufridas (art. 1328 inc. 10 Código Civil italiano) ${ }^{21}$. Este supuesto es considerado dentro de los denominados atti leciti dannosi ${ }^{22}$, que dan cuenta de una conducta permitida por el ordenamiento y otorgan como reparación una indennità y no a un risarcimento ${ }^{23}$. La indennità tendría únicamente una función reintegradora y existiría en los supuestos de ausencia de ilicitud del acto dañoso o ausencia de culpabilidad del autor del daño ${ }^{24}$. Se señala que la indennità es el remedio reparatorio de los daños no antijurídicos ${ }^{25}$, a diferencia del risarcimento, propio de la condena aquiliana ${ }^{26}$.

Así la cosas, la reparación en estudio obedece a una opción legislativa que busca no dejar desamparado al destinatario de una propuesta, que efectuó ciertos gastos e inversiones para dar una aceptación que no pudo otorgar por el ejercicio de la facultad de retractarse conferida al oferente. Como principio, se sostiene que el acto ontológicamente jurídico (lícito o debido) no produce consecuencias jurídicas ${ }^{27}$. Pero, en este caso, el legislador ha efectuado una evaluación de los intereses en conflicto, considerando injusto que el afectado soporte exclusivamente el menoscabo sufrido: ante el daño a la esfera económica y patrimonial de este, por razones de justicia material o equidad, estima razonable concederle una indemnización por aquel $^{28}$.

Apreciamos, en consecuencia, que el legislador arbitra la solución de un conflicto de intereses, para evitar que el destinatario de la oferta soporte exclusivamente los efectos adversos causados por el legítimo ejercicio del derecho de retractación.

\section{La indemnización por imposición de servidumbres legales}

Existen ciertas intervenciones en la propiedad privada, autorizadas por el legislador, que otorgan al perjudicado el derecho a reclamar una "indemnización". Es lo que ocurre corrientemente con la expropiación y, también, con la constitución de las servidumbres legales ${ }^{29}$.

Así, por ejemplo, para imponer la servidumbre de tránsito se exige el pago del valor del terreno necesario para la servidumbre y resarcir todo otro perjuicio (art. $847 \mathrm{CC})^{30}$. Algo similar acontece con la servidumbre de acueducto, en que se ordena pagar, por concepto de indemnización, el precio de todo el terreno que fuere ocupado, las mejoras afectadas por la construcción del acueducto y el de un espacio a cada uno de los costados, así como todo

\footnotetext{
${ }^{19}$ Algunos la fundamentan en el artículo 10 №10 CP, que exculpa de responsabilidad penal al que "obra en cumplimiento de un deber o en el ejercicio legítimo de un derecho, autoridad, oficio o cargo", CORRAL (2013), p. 124. En sentido similar RODRÍGUEZ (1999), pp. 159-162. Otros indican que el ejercicio de un derecho subjetivo usualmente excluye la ilicitud, BARROS (2020), p. 142. ${ }^{20}$ DÍEZ-PICAZO (1979,) p. 735.

21 "La proposta può essere revocata finché il contratto non sia concluso. Tuttavia, se l'accettante ne ha intrapreso in buona fede l'esecuzione prima di avere noticia della revoca, il proponente è tenuto a indennizzarlo delle spese e delle perdite subite per l'iniziata esecuzione del contratto".

22 TUCCI (1967), p. 238; MOROZZO (1998), p. 437; BUONAURO (2012), pp. 267 y ss.

${ }^{23}$ En contra se manifiesta Torregrossa, quien señala que la elección del concepto depende exclusivamente de la intención del legislador de excluir la indemnización en forma específica y no de un presunto carácter legal de los daños que la indemnización misma es llamada a compensar, TORREGROSSA (1964), p. 200. Véase CÉSPEDES (2016), nota 973, p. 190.

${ }^{24}$ MESSINEO (1958), pp. 562 y 563; CÉSPEDES (2016), p. 190.

25 DE CUPIS (1975), p. 759; CÉSPEDES (2016), pp. 309 y 310.

26 MAZZOLA (2007), p. 123. Yzquierdo aprecia la diferencia entre indennità y risarcimento, poniendo de manifiesto que el risarcimento es una noción que el Códice reserva para la auténtica responsabilità civile, YZQUIERDO (2001), p. 114. Véase CÉSPEDES (2016), nota 1418 , p. 310.

${ }^{27}$ DELL'ANDRO (1958), p. 550.

${ }^{28}$ BUSTO (1998), p. 166; LARENZ (1959), p. 690; BRIGUGLIO (1971), p. 173.

${ }^{29}$ CÉSPEDES (2018b), p. 137.

${ }^{30}$ CÉSPEDES (2018b), p. 137.
} 
perjuicio ocasionado por la construcción del acueducto y por sus filtraciones, derrames y desbordes que puedan imputarse a defectos de construcción o mal manejo del mismo (art. 82 Código de Aguas).

Pues bien, ciertamente no estamos en presencia de un resarcimiento propio de la responsabilidad civil $^{31}$, puesto que la compensación económica impuesta al beneficiado con la constitución de la servidumbre no tiene por objeto reparar un daño originado por un hecho ilícito ${ }^{32}$, pues no existe delito ni cuasidelito civil alguno. De ahí que se hable de "reparación de actos lícitos o legitimados"33; y que se indique que la analogía más profunda de esta clase de reparaciones lo sea con las restituciones provenientes del enriquecimiento sin causa, puesto que lo que existe es "una restitución de lo que se ha tomado del propietario en beneficio de un tercero que desarrolla la actividad $u$ obtiene el provecho amparado por la servidumbre respectiva" ${ }^{\prime 34}$. Y bien sabemos las grandes diferencias existentes entre la responsabilidad civil y el enriquecimiento injustificado ${ }^{35}$.

En efecto, la "indemnización" puesta de cargo del beneficiado por la constitución de la servidumbre legal no puede relacionarse con la violación de un deber de comportamiento, ya que ha sido la propia ley la que la ha permitido, excluyendo con ello la ilicitud de la conducta ${ }^{36}$. Asimismo, la norma que ha permitido la imposición de tal servidumbre y ordenado la correspondiente reparación excluye, de una parte, la tutela implícita del neminem laedere, y, de otra, entregan el instrumento para la reparación del equilibrio turbado ${ }^{37}$.

Así se ha entendido en el sistema comparado, ya que la obligación de indemnizar no nace de un acto ilícito $y$, en consecuencia, no se encuentra sometida al régimen común de responsabilidad civil por daño antijurídico ${ }^{38}$. Pantaleón refiere que se trata de un supuesto típico de la llamada "responsabilidad por acto lícito", "responsabilidad por ataques o transgresiones permitidos" (Haftung für erlaubte Eingriffe) o "responsabilidad o pretensión por el sacrificio" (Aufopferungshafttung, Aufopferungsansprunch), ajena a toda idea de culpa ${ }^{39}$. Se afirma que "el fundamento de este deber de indemnizar no radica en estos casos ni en la responsabilidad por un acto antijurídico propio o ajeno, ya que el ataque es conforme a Derecho por estar permitido, ni en la imputación de un determinado riesgo de cosa o de empresa, sino en la exigencia de justicia conmutativa de que aquel que ha defendido su interés en perjuicio del derecho de otro, aunque en forma autorizada, ha de indemnizar al perjudicado que hubo de soportar la perturbación de su derecho" 40 .

En este entendido, la indemnización concedida por la imposición de las servidumbres legales es completamente distinta de las genuinas indemnizaciones de daños ${ }^{41}$.

\section{La indemnización por daños causados en estado de necesidad}

Corral define al estado de necesidad como "el daño causado para evitar la realización del que amenaza a su autor o a un tercero" ${ }^{42}$. Barros sostiene que actúa sin culpa quien ocasiona un daño para evitar otro mayor. Agrega que esta causa de justificación se basa en la desproporción

\footnotetext{
31 PEÑAILILLO (2019), pp. 356 y ss.

32 CÉSPEDES (2016), pp. 301 y ss.

33 GHERSI (1997), pp. 478 y 479; CÉSPEDES (2019), p. 1051.

${ }^{34}$ BARROS (2020), p. 499.

${ }^{35}$ Entre varios, DÍEZ-PICAZO (1999), pp. 48 y ss.; BARROS (2009), pp. 26 y ss.

${ }^{36}$ BRIGUGLIO (1971), p. 174; MESSINEO (1958), p. 563. CÉSPEDES (2016), p. 266.

${ }^{37}$ BRIGUGLIO (1971), p. 175; CÉSPEDES (2016), p. 303.

38 BUSTO (1998), p. 165.

39 PANTALEÓN (1987), p. 328. También en PANTALEÓN (1991), p. 1995. Véase CÉSPEDES (2016), p. 305.

40 LARENZ (1959), p. 690. En el mismo sentido, LEHMANN (1956), p. 492, dando como ejemplo el establecimiento de una servidumbre de paso. Y pareciera que así lo entendía Ennecerus, al referirse a esta hipótesis como una especie de aquellos "actos sin culpa que obligan a indemnización", ENECCERUS (1950), pp. 450 y ss. Véase CÉSPEDES (2016), p. 308.

${ }^{41}$ DÍEZ-PICAZO (1999), pp. 56 y 57.

42 CORRAL (2013), p. 122. En el mismo sentido, AEDO (2006), p. 269.
} 
de los bienes comprometidos por la acción: la víctima soporta un daño que es substancialmente menor al daño actual o inminente que el autor pretende evitar ${ }^{43}$.

En la actualidad, tanto en nuestro país como en el Derecho comparado, existe una tendencia que se inclina por no considerarlo un supuesto de responsabilidad civil ${ }^{44}$, ya que no hay ilicitud ${ }^{45}$ y no hay daño injusto ${ }^{46}$. Por lo anterior, el estado de necesidad excluye la acción propiamente indemnizatoria de la víctima por el daño ocasionado, pero no obsta al ejercicio de la acción restitutoria del daño producido para obtener un provecho propio o ajeno, pues el derecho no puede amparar el enriquecimiento injusto de quien salva un bien propio con cargo al patrimonio de otro ${ }^{47}$.

No obstante no existir un daño ilícito o antijurídico, el menoscabo producido genera igual una reacción del ordenamiento en favor del perjudicado, consistente en una compensación económica en tutela de su interés, a fin de reequilibrar la situación comprometida ${ }^{48}$. Pero esta reparación no obedece a la lógica de la responsabilidad civil, puesto que no existe acto ilícito alguno y, por lo mismo, la fuente de tal obligación no son los delitos o cuasidelitos civiles ${ }^{49}$.

Por otro lado, al no existir en nuestro país norma expresa que regule esta indemnización, la consecuencia reparatoria que admite nuestra doctrina se fundamenta en el enriquecimiento sin causa - como se dijo- y que, bien sabemos, además de considerarse como fuente autónoma de obligaciones ${ }^{50}$, constituye una institución distinta de la responsabilidad civil ${ }^{51}$, desde que no exige culpa del agente y la extensión de la restitución se mide en relación al enriquecimiento y no al daño causado.

Más aún, en los ordenamientos que contemplan expresamente una compensación por los daños causados en estado de necesidad ${ }^{52}$, se reconduce su existencia directamente a las obligaciones "ex lege", indicándose que las disposiciones que regulan el estado de necesidad son normas permisivas o autorizantes que derogan el principio general de no causar daño a otro. En virtud de aquello, se permite realizar un comportamiento productor de perjuicios para terceros $^{53}$, pero que generan daños justos ${ }^{54}$.

\footnotetext{
${ }^{43}$ BARROS (2020), p. 145.

${ }^{44}$ BARROS (2020), p. 146; CORRAL (2013), p. 123; DÍEZ-PICAZO (1999), p. 302; YZQUIERDO (2001), p. 114; DE ÁNGEL (1993), p. 285; BUSTO (1998), p. 171; BENÍTEZ (2005), p. 34. Hay quienes sostienen que tal indemnización surge de un cuasicontrato de "assistance bénévole" fundado en tal principio, o bien, en la gestión de negocios ajenos, VINEY y JOURDAIN (2013), p. 671; GORDLEY y TALOR (2006), p. 225. Otros lo califican derechamente como un supuesto de daño no antijurídico que excepcionalmente da lugar a una reparación DE CUPIS (1975), p. 93. Sin embargo, existen opiniones que estiman que podría constituir más bien una fuente autónoma de responsabilidad civil, VINEY y JOURDAIN (2013), p. 671. O que la autorización legal de un comportamiento potencialmente dañoso no elimina la ilicitud del mismo, máxime si se ha impuesto una reparación por su acaecimiento, TRIMARCHI (1961), pp. 18 y ss. 0 que la responsabilidad derivada de un acto lícito legal no es excepcional en la ratio del instituto de la responsabilidad civil, dado que esta es principalmente una reacción al daño injusto, entendiendo por tal a aquél que se sustenta en la lesión de un interés del dañado tutelado por el ordenamiento, lo que incluso puede acontecer cuando el acto del cual emane sea lícito, TUCCI (1967), pp. 263 y 264; PERLINGIERI (2004), p. 1079; MAZZOLA (2007), p. 159. La última parte de la discusión puede verse en CÉSPEDES (2018b), pp. 139 y 140.

45 YZQUIERDO (2001), p. 114; BRUN (2015), pp. 308 y ss. Así también el art. 339.1 del Código Civil portugués: "É lícita a acção daquele que destruir ou danificar coisa alheia com o fim de remover o perigo actual de um dano manifestamente superior, quer do agente, quer de terceiro". Así lo reconoce la doctrina alemana, en que la existencia de una justificación (Rechtfertigungsgrund) elimina la ilicitud (Rechtswidrigkeit), MARKESINIS et al. (2019), pp. 49 y 50. Véase CÉSPEDES (2016), nota 1306, p. 286.

${ }^{46}$ DE ÁNGEL (1993), p. 285. Asimismo, de los arts. 1717 y 1718 del Código Civil y Comercial argentino se desprende que es un daño no antijurídico. Véase CÉSPEDES (2018b), p. 137.

47 BARROS (2020), p. 146. En el mismo sentido, CORRAL (2013), p. 123; y RODRíGUEZ (1999), p. 157, aunque califica la acción como indemnizatoria. También AEDO (2006), pp. 269 y 270, pero entendiendo que se ha ampliado el criterio de la responsabilidad fue ra de los estrictos márgenes del Código Civil. En el Derecho comparado también se reconoce como fundamento al enriquecimiento sin causa, DÍEZ-PICAZO (1999), pp. 301 y 302; GARCÍA-RIPOLL (2006), p. 154.

${ }^{48}$ DE CUPIS (1975), p. 24. Véase CÉSPEDES (2016), p. 290.

${ }^{49}$ Incluso se ha calificado al acto necesitado como una hipótesis de fuerza mayor BIANCA (2019), p. 665.

${ }^{50}$ A nivel jurisprudencial, sentencias de la Corte Suprema, Rol № 38.887-2017, de 17 de diciembre de 2018; Rol № 44.324-2017, de 03 de septiembre de 2018; Rol № 32.990-2016, de 03 de enero de 2017. También la doctrina, PEÑAILILLO (1996), pp. 7 y ss.; ABELIUK (2014), pp. 223 y ss.

51 BARROS (2009), pp. 26 y ss.; PEÑAILILLO (1996), p. 29.

${ }^{52}$ Por ejemplo, art. 2045 del Código Civil italiano; art. 339 del Código Civil portugués; art. 118.1 del Código Penal español; art. 1718 letra c) del Código Civil y Comercial argentino.

${ }^{53}$ BRIGUGLIO (1971), p. 160.

${ }^{54}$ BUSTO (1998), p. 383.
} 
De esta manera, ciertamente la indemnización en comento no constituye un supuesto de responsabilidad civil.

\section{Las indemnizaciones dispuestas en algunas formas de accesión}

A propósito de este modo de adquirir, se comprenden en su regulación algunas formas de accesión que conceden al titular de la propiedad sacrificada una "indemnización" como consecuencia de haber operado tal modo.

Así ocurre en la especificación, en que no habiendo conocimiento del hecho por una parte ni mala fe por otra, y siempre que la nueva especie valga más la materia, se atribuye la propiedad al especificante, pero a cambio de pagar una indemnización de perjuicios al dueño de la materia (art. 662 inc. 2ㅇ y 3으). 0 en el caso de edificación, plantación o siembra en terreno ajeno, en que "el dueño del terreno en que otra persona, sin su conocimiento, hubiere edificado, plantado o sembrado, tendrá el derecho de hacer suyo el edificio, plantación o sementera, mediante las indemnizaciones prescritas a favor de los poseedores de buena o mala fe en el título De la reivindicación..." (art. 669 inc. 10 CC).

En las formas de accesión señaladas precedentemente, la indemnización concedida no la podemos considerar como un supuesto de responsabilidad civil, dado que no existe reproche alguno a la conducta del que debe satisfacerla. Así, en la especificación, se exige expresamente "buena fe" de una parte y "ausencia de conocimiento" de la otra, que son comportamientos incompatibles con la aplicación de las normas de los delitos y cuasidelitos civiles del Título XXXV CC. Por lo demás, cuando el legislador ha querido hacer referencia a estos, lo ha hecho calificando la conducta como culposa o dolosa del obligado a ella, como ocurre en los arts. 667 inc. 1 - y 668 inc. $2^{\circ} \mathrm{CC}$ (al referirse a la respectiva actuación como "sin justa causa de error" o "a sabiendas"), lo que no acontece en el caso enjuiciado.

Lo dicho precedentemente también lo constatamos respecto de las indemnizaciones que manda pagar el art. 669 inc. 1 CC al dueño del terreno que opta por hacer suyo el edificio, plantación o sementera, que se rige por las normas de las prestaciones mutuas (arts. 904 y ss. CC). Se ha dicho que estas últimas, en la parte en que resultan aplicables al dueño del terreno, no tienen por fundamento las normas de la responsabilidad civil, ya que no existe un sujeto culpable o malicioso que lo haya causado, sino que se fundan en el enriquecimiento ilícito que podría producirse en caso de que el propietario del terreno recibiera una cosa con mejoras que él no efectuó, resultando injustamente empobrecido aquel que edificó, plantó o sembró ${ }^{55}$.

En este entendido, las indemnizaciones que la ley prevé en favor de aquellos cuya propiedad ha resultado sacrificada, lo son en consideración de que su derecho o ventaja también es merecedor de protección por el ordenamiento a través de la debida compensación, normalmente equivalente al valor de la materia perdida o de la obra ejecutada ${ }^{56}$. Así las cosas, los supuestos analizados no implican responsabilidad civil alguna del obligado a la "indemnización", desde que, además, son analizados por la doctrina bajo el rótulo del principio de interdicción del enriquecimiento $\sin$ causa $^{57}$ y no del neminem laedere. Por lo tanto, el sistema hace coexistir dos derechos o intereses que son inconciliables entre sí, por medio de la prevalencia de uno de ellos a cambio de una compensación económica en beneficio del titular del derecho o interés sacrificado, logrando, con ello, equilibrar la situación jurídica inicialmente desbalanceada por la opción legislativa ${ }^{58}$.

\footnotetext{
55 PINOCHET y CONCHA (2015), p. 148. En el mismo sentido, BARRIENTOS (2017), p. 84. Así también lo ha reconocido la jurisprudencia, por ejemplo, Corte Suprema, Rol № 38.887-2017, de 17 de diciembre de 2018, en la cual para acoger una acción in rem verso fundada en el enriquecimiento sin causa, acudió a esta expresa disposición para concederla.

${ }^{56}$ CÉSPEDES (2016), p. 282.

${ }^{57}$ BASOZABAL (1998), p. 269; PINOCHET y CONCHA (2015), p. 148; BARRIENTOS (2017), p. 84; PINO (2019), pp. 383 y ss.

${ }^{58}$ CÉSPEDES (2016), p. 283.
} 


\section{La indemnización expropiatoria}

El inc. 3o del № 24 del artículo 19 de nuestra Constitución, al regular la expropiación, dispone que el expropiado tendrá siempre derecho a la indemnización por el daño patrimonial efectivamente causado, la que se fijará de común acuerdo o en sentencia dictada conforme a derecho por dichos tribunales.

Es pacífico afirmar que la indemnización expropiatoria es ajena a la responsabilidad civil${ }^{59}$. En primer lugar, porque el Estado, al dictar una ley expropiatoria, ejerce una facultad legítima y autorizada por el ordenamiento ${ }^{60} \mathrm{y}$, por lo mismo, tal conducta no puede reprocharse de ninguna forma. Asimismo, porque la obligación de pagar la correspondiente indemnización debe ser concebida como una carga a cumplir por el Estado ${ }^{61}$, es decir, surge ex ante de que se produzca la privación de la situación jurídico-patrimonial en que la expropiación consiste, mientras que en la responsabilidad civil el deber de indemnizar surge siempre ex post ${ }^{62}$.

Se agrega que la finalidad de tal indemnización es esencialmente restitutoria: la suma pagada es en retribución de aquello de lo cual el administrado es privado ${ }^{63}$. 0 sea, no es más que "reintegrar por equivalente" el valor de una cosa o de un atributo, por medio de un justiprecio ${ }^{64}$. De ahí que se insista en que la expropiación es una técnica de conversión de derechos: el bien expropiado se convierte en su valor económico, por el cual la pérdida del bien objeto de la expropiación se compensa con un crédito sobre su justo precio ${ }^{65}$.

Es preciso consignar que la confusión entre expropiación y responsabilidad civil se puede atribuir a que la responsabilidad patrimonial de la Administración tiene su origen en el reconocimiento y posterior expansión del concepto de indemnización expropiatoria, erigiéndose como un anexo problemático de esta ${ }^{66}$. Esta cercanía, incluso, ha llevado en algunos ordenamientos a su estudio y tratamiento conjunto, como en Alemania o España ${ }^{67}$.

Por lo tanto, también descartamos que la expropiación constituya un supuesto de responsabilidad civil.

No existe daño ilícito o antijurídico alguno y la indemnización concedida trae como causa la existencia de daños lícitos o restituciones de enriquecimientos

El análisis de los casos anteriores nos lleva a concluir que la indemnización concedida en cada una de ellos no lo es a título de responsabilidad civil.

En efecto, tal reparación no tiene por causa reproche alguno que formular a la conducta del obligado a ella, desde que el comportamiento dañoso ha sido autorizado y permitido expresamente por el ordenamiento. Recordemos que la responsabilidad consiste en una desvalorización del comportamiento del sujeto, erigiéndose como mecanismo de restablecimiento o recomposición del orden normativo violado ${ }^{68}$. La represión de la conducta lesiva responde a una elemental exigencia ética: el autor del daño responde de él, responsabilidad que se traduce en la obligación de indemnizar o reparar los perjuicios causados a la víctima ${ }^{69}$. Ello emana del propio concepto de responsabilidad, definido como "la reacción del Derecho ante la infracción de una de sus normas, por parte del comportamiento de un

\footnotetext{
59 BARROS (2020), pp. 540-542; MONTORY (2019), pp. 112 y ss; CÉSPEDES (2016), p. 156. En el Derecho comparado, por ejemplo, GARCÍA DE ENTERRÍA (1984), pp. 112 y ss.; BARNÉS (1995), p. 55; TARDÍO (2000), pp. 82 y ss.; KIMMINICH (1995), p. 169.

${ }^{60}$ Se habla del "ejercicio legítimo de una potestad pública en cautela del interés general", BARROS (2020), p. 512.

${ }^{61}$ GARCÍA DE ENTERRÍA (1984), p. 114.

62 TARDÍO (2000), p. 82; CÉSPEDES (2016), pp. 156 y 157.

${ }^{63}$ BARROS (2020), p. 512. En el sistema alemán se señala que solo busca compensar el valor perdido por aquello de que es privado el particular en beneficio del bien común, MARKESINIS et al. (2019), p. 188.

64 MONTORY (2019) p. 118. En el mismo sentido, DÍEZ-PICAZO (1991), pp. 1269 y 1270.

${ }^{65}$ GARCÍA DE ENTERRÍA y FERNÁNDEZ (2017), p. 305.

${ }^{66}$ FORSTHOFF (1958), p. 426; CÉSPEDES (2016), p. 100.

${ }^{67}$ MONTORY (2019), pp. 113 y 114; CÉSPEDES (2018a), pp. 86 y ss.

${ }^{68}$ KRAUSE (2015), pp. 54 y 55; LÓPEZ (2019), p. 20.

69 DE ÁNGEL (1993), p. 13; CÉSPEDES (2016), p. 297.
} 
agente moral destinatario de las mismas, consistente en la realización de un reproche que se manifiesta en la consecuencia jurídica enlazada con dicha violación normativa" ${ }^{70}$. De esta manera, la responsabilidad civil surge como consecuencia de un comportamiento reprochado por el sistema que causa un daño ilícito o antijurídico. De tal manera que todo daño, pérdida o menoscabo económico que no traiga como causa tal juicio de reproche ${ }^{71}$, no podemos considerarlo como una hipótesis de tal responsabilidad.

Por otro lado, tal indemnización no lo es a consecuencia de un daño ilícito o antijurídico, ya que el resultado lesivo o perjudicial se encuentra amparado por la norma que autorizó la conducta dañosa, concurriendo la causal de justificación de ejercicio legítimo de un derecho ${ }^{72}$. Solo el daño no justificado es el que permite hablar de responsabilidad civil, ya que esta última se controla mediante la idea del ejercicio del derecho de obrar: solo se atribuye al causante el daño injusto, y únicamente se considera injusto el perjuicio que es causado sin derecho ${ }^{73}$, lo que aquí no se aprecia. Así, la licitud del acto excluye la injusticia del daño ${ }^{74}$, aserto que, incluso, transforma en irresarcibles ciertos perjuicios manifiestos, como los causados en el legítimo ejercicio del derecho de huelga ${ }^{75}$ o con motivo de la legítima defensa ${ }^{76}$. Por lo demás, el daño ordenado reparar no se ha imputado al obligado a pagarlo en base a la culpa o negligencia o de un determinado riesgo ${ }^{77}$, sino por razones de justicia material o de equidad ${ }^{78}$, por la cual el titular del interés privilegiado ha de reparar al perjudicado que hubo de soportar la perturbación de su derecho.

En otras palabras, la inexistencia de una conducta reprobada por el ordenamiento y de un daño antijurídico impiden la configuración de un ilícito civil, condición necesaria para hablar de responsabilidad civil79. $^{79}$.

Abona la conclusión anterior, el hecho que la indemnización concedida en los supuestos estudiados lo es como consecuencia de la existencia de daños lícitos, o bien, de restitución de enriquecimientos. En efecto, los daños lícitos ${ }^{80}$ son aquellos que emanan de acciones o conductas ajustadas a Derecho, caracterizados por la ausencia de transgresión a un deber jurídico ${ }^{81}$ y que, cuando generan una obligación indemnizatoria, no lo son a título de responsabilidad civil $^{82}$, sino que por razones de justicia material o de equidad ${ }^{83}$. Más aun, de no

\footnotetext{
70 SANZ (2001), pp. 49 y 50. En sentido similar, BONET (1981), p. 428. Se ha dicho que, en un sentido muy amplio, el método de exclusión permite hablar de responsabilidad cada vez que resulta incumplido un deber de carácter jurídico YZQUIERDO (2015), p. 23. LÓPEZ (2019), p. 550, indica que sin obligación preexistente o deber jurídico incumplido, nunca puede configurarse un supuesto de obligación resarcitoria. BIANCA (2019), p. 559, refiriéndose a la responsabilidad extracontractual, señala que ella tiene lugar por la violación de una norma de conducta que regula la vida social y que impone deberes de respeto de los intereses de otro.

${ }^{71}$ Se ha sostenido que en los casos más tradicionales de responsabilidad civil, la responsabilidad se afirma precisamente a causa de una infracción de un estándar de conducta determinado, WILENMANN (2017), p. 294.

72 BARROS (2020), pp. 141 y 142; CORRAL (2013), p. 124; RODRÍGUEZ (1999), pp. 159 y 160.

73 LLAMAS (2010b), p. 53.

${ }^{74}$ BIANCA (2019), p. 569.

75 KARILA DE VAN (1995), pp. 537 y 538

${ }^{76}$ CÉSPEDES (2016), pp. 79 y ss.

77 Pantaleón afirma que se indemniza a título de responsabilidad civil no porque se haya obrado antijurídicamente, sino porque el daño es imputable a la conducta del agente sobre la base de la culpa, PANTALEÓN (1991), p. 1995. En el mismo sentido, YZQUIERDO (2001), p. 112; CÉSPEDES (2016), p. 176. Más ampliamente se ha sostenido “... que hoy sólo constituye presupuesto necesario de la responsabilidad civil la propia existencia del daño, por un lado, y su atribución a un determinado sujeto en virtud de un ade cuado título de imputación por otros. Este ha de provenir necesariamente de una norma y se sustenta no sólo en el dolo o la culpa del dañante, sino sobre circunstancias de muy diversa índole (relación con personas o cosas, ejercicio de una determinada actividad, titularidad de bienes...", REGLERO y PEÑA (2015), p. 74. El binomio daño y criterio de imputación se consagra en los Principios Europeos de Responsabilidad Civil (PETL) y en el denominado Marco Común de Referencia (DCFR).

78 BUSTO (1998), p. 166. LARENZ (1959), p. 690, sostiene que la indemnización que se concede lo es por razones de justicia conmutativa. BRIGUGLIO (1971), p. 173, sostiene que lo es por razones de justicia distributiva, ya que su única finalidad es restablecer el equilibrio económico entre los patrimonios afectados: repartir las consecuencias no injustas de una situación no querida. Véase CÉSPEDES (2016), nota 52, p. 42.

79 BRUN (2015), p. 267; BIANCA (2019), pp. 543-545.

80 CÉSPEDES (2016), pp. 42, 43, 170 y 171.

${ }^{81}$ BRIGUGLIO (1971), p. 174. CÉSPEDES (2016), p. 41.

82 TUCCI (1967), p. 231 y ss.; DE CUPIS (1975), pp. 93 y ss.; BUSTO (1998), pp. 166 y 192; GHERSI (1997), p. 478. Que la indemnización concedida no lo sea a título de responsabilidad civil, permite distinguir a esta clase de actos de los supuestos de respons abilidad objetiva, en que el resarcimiento concedido si lo es a ese respecto. Véase CÉSPEDES (2016), p. 41.

83 BUSTO (1998), p. 166; LARENZ (1959), p. 690; BRIGUGLIO (1971), p. 173; CÉSPEDES (2016), p. 42.
} 
haberse establecido tal indemnización por la ley, ella no habría nacido, por cuanto -como se dijo- no se reparan los perjuicios causados en el ejercicio de un derecho o facultad.

En estos casos, el daño no puede calificarse de ilícito, no solo porque la conducta generadora del mismo es lícita, sino, esencialmente, porque la posibilidad de inferir daños se comprende dentro del radio de acción de la conducta autorizada por el ordenamiento ${ }^{84}$. De esta manera, el daño lícito se caracteriza por ser un daño tolerado y permitido por el ordenamiento ${ }^{85}$. Normalmente se identifica con la existencia de una norma permisiva que autoriza la ejecución de un comportamiento dañoso, de tal suerte que el perjuicio resultante se califica como no antijurídico o simplemente justo ${ }^{86}$. Por ello, se dice que aquellos están constituidos por ciertos daños que el ordenamiento jurídico no repele, que algunas veces tolera y que incluso puede favorecer ${ }^{87}$.

En el mismo orden de ideas, algunos de los supuestos examinados corresponden a casos de restituciones de enriquecimientos, que se encuentran anudados al principio de interdicción del enriquecimiento injustificado, institución bastante distinta a la responsabilidad civil. Así, la medida de la restitución es la ganancia injustificada y no el perjuicio causado, ya que la lógica de la acción de enriquecimiento es la justicia restitutoria y no la correctiva; la obligación restitutoria es primaria, ya que no deriva del incumplimiento de una obligación ni de la infracción de un deber de cuidado; $y$, las acciones restitutorias no reconocen como antecedente un hecho ilícito, ya que no exige la concurrencia de dolo o culpa ${ }^{88}$.

Lo anterior, permite corroborar la absoluta ajenidad al estatuto de la responsabilidad civil de los casos contemplados bajo el rótulo de "responsabilidad por acto o hecho lícito".

\section{Las indemnizaciones derivadas de hechos o actos lícitos constituyen supuestos de indemnizaciones o compensaciones por sacrificio}

Conforme a lo expuesto y descartada la pertenencia de esta clase de indemnizaciones a aquellas propias de la responsabilidad civil, sostenemos que las reparaciones concedidas con motivo de la mal denominada "responsabilidad por hechos o actos lícitos" constituyen supuestos de indemnizaciones o compensaciones por sacrificio ${ }^{89}$.

Las indemnizaciones por sacrificio son aquellas compensaciones que las leyes atribuyen a determinados sujetos como consecuencia de la pérdida, ablación o limitación forzosa de derechos subjetivos o como recompensa parcial del sacrificio que se exige a los titulares ${ }^{90}$. Así las denomina Díez-Picazo, donde admite un uso amplio y equívoco de la palabra "indemnización", pero en el entendido que aquellas son netamente distintas a las genuinas "indemnizaciones de daños" propias de la responsabilidad civil. Y reserva esta denominación precisamente a varias de las hipótesis que mencionaban los autores arriba mencionados, como algunas formas de accesión, ciertas servidumbres legales y el justiprecio de las expropiaciones forzosas ${ }^{91}$

Se ha sostenido que sus funciones son las siguientes: solucionar un conflicto de intereses, permitir la restitución de enriquecimientos obtenidos a costa de otros, otorgar licitud a un acto objetivamente ilícito y limitar el quantum reparatorio ${ }^{92}$.

\footnotetext{
${ }^{84}$ CÉSPEDES (2018b), pp. 132 y 133; CÉSPEDES (2016), p. 42.

${ }^{85}$ CÉSPEDES (2018b), p. 133.

86 BRIGUGLIO (1971), p. 160; CÉSPEDES (2016), pp. 185 y ss.

87 DÍEZ-PICAZO (1999), p. 294; CÉSPEDES (2018b), p. 134.

88 BARROS (2009), pp. 27-29; CORRAL (2013), pp. 57 y 58; DÍEZ-PICAZO (2007), p. 238.

${ }^{89}$ CÉSPEDES (2019), pp. 1041 y ss.

90 DÍEZ-PICAZO (1999), pp. 56 y 57. En el sistema chileno estas compensaciones se conocen con el nombre de "indemnizaciones por afectación lícita de derechos", CORRAL (2013), pp. 58 y 59. Véase CÉSPEDES (2018b), p. 149.

${ }^{1}$ DÍEZ-PICAZO (1999), p. 57; CÉSPEDES (2016), p. 299.

92 CÉSPEDES (2019), pp. 1048 y ss.
} 
Nos parece más precisa la denominación "compensaciones por sacrificio", por cuanto la medida de la reparación se extiende solo al daño, pérdida o menoscabo patrimonial sufrido

Por nuestra parte, preferimos denominarlas "compensaciones por sacrificio", porque tal concepto evidencia el contenido de la prestación a que tiene derecho el perjudicado: una "compensación" para obtener la restitución de los enriquecimientos obtenidos por el beneficiado por ellos o para restablecer el equilibrio roto por el daño y como una forma de reparación del mismo ${ }^{93}$. Más aun, se ha sostenido que la expresión "indemnizar" resulta una expresión ambigua, pues en unas ocasiones se le atribuye un significado equivalente a reparar y en otras se emplea como sinónimo de resarcir, en el estricto sentido específico de reparación mediante equivalente pecuniario, que pareciera ser la correcta, por su carácter específico y restringido ${ }^{94}$.

La voz "compensación" no resulta ajena a nuestro sistema, ya que se le utiliza en términos similares al estudiado en distintas materias. Así, por ejemplo, los arts. 28 y ss. del D.L. 2.695, sobre saneamiento de la pequeña propiedad raíz, regula a la "compensación de derechos en dinero", que permite a los terceros que acrediten dominio sobre todo el inmueble o una parte de él y que no hayan ejercido oportunamente las acciones de dominio sobre el predio saneado - así como los que pretendan derechos de comunero sobre el mismo o ser titulares de algún derecho real que lo afecte-, exigir que tales derechos le sean compensados en dinero en la proporción que corresponda hasta la concurrencia del valor del predio (art. 28 D.L. 2.695).

También la encontramos en la institución de la compensación económica, respecto de la cual la doctrina destaca que no pretende indemnizar ampliamente al cónyuge acreedor ni otorgarle un valor equivalente al lucro cesante sufrido durante la vida conyugal, puesto que lo que busca es otorgarle una satisfacción económica que mitigue la situación patrimonial desmedrada del afectado ${ }^{95}$. Tampoco pretende nivelar la situación patrimonial de ambos cónyuges ni mantener el mismo nivel de vida, sino dejarlo en condiciones para enfrentar dignamente la vida futura ${ }^{96}$. Tan así, que incluso algunos autores la tratan precisamente como un ejemplo de indemnización por sacrificio ${ }^{97}$, indicando que evoca la idea de corrección, nivelación o igualación ${ }^{98}$.

El concepto "compensar" tampoco es desconocido en el Derecho comparado. En el ordenamiento alemán existe la denominada "delimitación de derechos necesitada de compensación" (ausgleichspflichtige Inhaltsbestimmung), que constituye una excepción a la regla general de que la delimitación de derechos no trae aparejada indemnización alguna ${ }^{99}$. En virtud de ella, cuando una regulación legal limite la propiedad de una forma general ajustada a la Constitución, pero, en algunos casos concretos, genere cargas especiales injustificables e inexigibles desde la perspectiva de los principios de proporcionalidad e igualdad, la ley debe prever una indemnización, so pena de inconstitucionalidad ${ }^{100}$.

Giorgi, refiriéndose a la indemnización expropiatoria, prefería denominar tal reparación económica como "compensación": “...pero como en nuestra legislación faltan reglas precisas que regulen la materia de las compensaciones debidas a los particulares por las lesiones al derecho individual impuestas por las exigencias del interés público, por esto ocurre que las dos indagaciones frecuentemente se confunden, y la jurisprudencia recurre a la teoría del resarcimiento del daño para encontrar el fundamento del derecho de indemnización, que mejor

\footnotetext{
${ }^{93}$ LLAMAS (2010a), p. 8; CÉSPEDES (2016), p. 43.

94 LLAMAS (2010a), p. 9; DE CUPIS (1975), pp. 822 y 823; CÉSPEDES (2016), p. 202.

${ }^{95}$ DOMÍNGUEZ (2007), p. 89; CÉSPEDES y VARGAS (2008), p. 451.

${ }^{96}$ CÉSPEDES y VARGAS (2008), p. 453.

${ }^{77}$ CORRAL (2007), pp. 23 y ss.; VIDAL (2004), pp. 284 y ss.

${ }^{98}$ VIDAL (2004), p. 285.

${ }^{99}$ CÉSPEDES (2016), p. 149.

${ }^{100}$ MIR (2002), p. 114; BARNÉS (1995), p. 50; MENÉNDEZ (2013), pp. 74 y 75. En materia ambiental, KAHL (1995), p. 786; CÉSPEDES (2016), p. 150.
} 
debería llamarse compensación, con respecto al derecho individual sacrificado" ${ }^{101}$. En el sistema español, Mariano Alonso designa como "compensaciones" a las indemnizaciones derivadas de algunas clases de accesión ${ }^{102}$. Y en el mismo ordenamiento se ha designado de la misma forma a la reparación de los daños causados con motivo del estado de necesidad: "... no se debe en concepto de responsabilidad civil, sino de "compensación" ante un perjuicio que, aunque justamente ocasionado, hay que compensar de alguna forma"103.

Un significado equivalente encontramos en el sistema italiano con la voz indennità, que presenta un carácter compensatorio más que sancionatorio ${ }^{104}$. La indennità tendría únicamente una función reintegradora y existiría en los supuestos de ausencia de ilicitud del acto dañoso o ausencia de culpabilidad del autor del daño ${ }^{105}$, dando lugar a una reparación limitada, por cuanto no coincide necesariamente con la exacta extensión del perjuicio ${ }^{106}$. Se diferencia del risarcimento, propio de la condena aquiliana ${ }^{107}$, puesto que se afirma que es el remedio reparatorio de los daños no antijurídicos ${ }^{108}$ o lícitos. Por lo demás, el risarcimento se impone al responsable de la lesión injusta de un interés como consecuencia de la violación de su norma protectora ${ }^{109}$. Finalmente, la ratio de la indennità tiene su fundamento en la equidad, como manifestación de un principio de justicia distributiva ${ }^{110}{ }^{111}$. Pues bien, varios de los casos que forman parte de la denominada "responsabilidad por hecho o acto lícito" dan lugar a esta reparación en Italia, como en el caso de la constitución de las servidumbres coactivas o legales ("... la sentenza stabilisce le modalità della servitù e determina l'indennità dovuta", art. 1032 CC italiano) o de los daños causados en estado de necesidad ("... al danneggiato è dovuta un'indennità, la cui misura e rimessa all'equo apprezzamento del giudice", art. 2045 Codice) ${ }^{112}$.

Incluso, respecto de lo último apuntado y basado en la diferencia de la extensión del daño reparable, se sostiene, en sede expropiatoria del sistema alemán, que una distinción terminológica semejante a risarcimento e indennità se manifiesta con las palabras Schadensersatz y Entschädigung: la primera persigue situar a la víctima en la posición en la que se encontraría de no haberse producido el daño; la segunda se limita a restituir el valor del bien o derecho dañado ${ }^{113}$.

Asimismo, el término "compensación" da cuenta de la lógica restitutoria que se encuentra tras esta clase de reparaciones ${ }^{114}$. La idea fuerza que subyace es la de mantener el equilibrio entre los intereses en conflicto ${ }^{115}$, lo que se traduce en que se autoriza el ejercicio del derecho que la legislación considera meritorio de mayor tutela y, como contrapartida, se concede una compensación económica al titular del interés afectado por dicha autorización ${ }^{116}$. En este escenario, tal prestación se convierte en el instrumento adecuado para reparar el equilibrio

\footnotetext{
101 GIORGI (1911), p. 264; CÉSPEDES (2016), nota 1404, p. 307. En el ámbito del Derecho público italiano, SCOTTI (2014), pp. 38 y ss.

${ }^{102}$ ALONSO (1980), p. 255.

103 YZQUIERDO (2015), p. 151. Véase CÉSPEDES (2016), p. 305.

104 TUCCI (1967), p. 249.

105 MESSINEO (1958), pp. 562 y 563; CÉSPEDES (2016), p. 190.

106 GUALANDI (1962), p. 383.

107 MAZZOLA (2007), p. 123.

108 DE CUPIS (1975), p. 759.

${ }^{109}$ DE CUPIS (1975), p. 759; MAZZOLA (2007), p. 124. Se afirma que el mérito de utilizar el término indennità es solo el de destacar

la naturaleza de compensación por hecho lícito, MOROZZO (1998), p. 435. Véase CÉSPEDES (2016), p. 310.

${ }^{110}$ ALESSI (1968), p. 628; CÉSPEDES (2016), p. 310.

${ }^{111}$ En todo caso, debemos destacar que hay opiniones en la doctrina italiana que consideran insuficiente sostener la distinción entre indennità y risarcimento en el carácter lícito o ilícito del hecho generador del daño como en la diferencia de la extensión de la reparación, PERLINGIERI (1980), p. 1067. Véase CÉSPEDES (2016), p. 310.

112 CÉSPEDES (2016), p. 309.

113 MIR (2002), nota 96, p. 78; CÉSPEDES (2016), nota 1429, p. 310.

114 BARROS (2020), p. 1043.

${ }^{115}$ GIACOBBE (2005), p. 102; TORREGROSSA (1964), p. 75.

${ }^{116}$ CÉSPEDES (2016), p. 171.
} 
turbado $^{117}$ o restablecer el equilibrio patrimonial roto ${ }^{118}$ por la disposición normativa que autoriza el comportamiento dañoso ${ }^{119}$.

La voz "compensación" permite, además, dar cuenta de que tal prestación económica cumple la función de restituir, restaurar o reintegrar el valor del bien o interés sacrificado ${ }^{120}$, teniendo un alcance más limitado que la típica indemnización de daños de la responsabilidad civil, en que rige el principio de reparación integral. En efecto, ello se puede deducir fácilmente respecto de las restituciones de enriquecimientos a que puedan dar lugar las compensaciones por sacrificio, en que el monto de la restitución está dado por el enriquecimiento o ganancia injustificada ${ }^{121}$, como puede apreciarse respecto de aquellas "indemnizaciones" concedidas en las situaciones de accesión -que tienen por objeto restablecer el desajuste económico o el desequilibrio patrimonial sufrido por el perjudicado y que se traduce en el abono del valor de lo perdido por esta causa ${ }^{122}$ - o en algunos supuestos de daños causados en estado de necesidad, arriba reseñados.

También lo podemos vislumbrar respecto de aquellas agresiones o afectaciones a la propiedad de otro autorizadas por la ley (que constituyen supuestos de daños lícitos), en que la compensación concedida busca reponer o reintegrar el patrimonio del titular del interés sacrificado. Es lo que ocurre con la expropiación, en que se ha afirmado que la indemnización del "daño patrimonial efectivamente causado" (art. 38 del D.L. 2186, Ley Orgánica de Procedimiento de Expropiaciones) lo es en retribución de aquello de lo cual el administrado es privado ${ }^{123}$, afirmándose que no es más que "reintegrar por equivalente" el valor de una cosa o de un atributo, por medio de un justiprecio ${ }^{124}$. De allí que la opinión mayoritaria enseñe que aquella comprenda solo el daño patrimonial y el lucro cesante causado por la expropiación, excluyéndose la reparación del daño moral ${ }^{125}$.

Lo mismo apreciamos respecto de varias de las servidumbres legales que contempla nuestro sistema. Así ocurre respecto de la servidumbre legal de acueducto, por el cual "el dueño del predio sirviente tendrá derecho a que se le pague, por concepto de indemnización, el precio de todo el terreno que fuere ocupado y las mejoras afectadas por la construcción del acueducto; el de un espacio a cada uno de los costados, que no será inferior al cincuenta por ciento del ancho del canal, con un mínimo de un metro de anchura en toda la extensión de su curso, y que podrá ser mayor por convenio de las partes o por disposición del Juez, cuando las circunstancias lo exigieren, para contener los escombros provenientes de la construcción del acueducto y de sus limpias posteriores y un diez por ciento adicional sobre la suma total. Dicho espacio, en caso de canales que se desarrollen por faldeos pronunciados, se extenderá en su ancho total por el lado del valle" (art. 82 inc. 10 Código de Aguas). O respecto de las servidumbres sobre presas, bocatomas, descargas, estribos, centrales hidroeléctricas, casas de máquinas u otras que está autorizado a imponer el titular de un derecho de aprovechamiento de agua respecto de los titulares de las riberas, terrenos o cauces en que deba usar, extraer, descargar o dividir las aguas, en que la indemnización respectiva comprende el valor del terreno y las indicadas en el citado art. 82 (art. 96 Código de Aguas).

\footnotetext{
${ }^{117}$ BRIGUGLIO (1971), p. 175. En el mismo sentido, BUSTO (1998), p. 383.

118 DÍEZ-PICAZO (1966), pp. 846, 853 y 854; ALONSO (1983), pp. 255, 257, 261 y 267; CARRASCO (1986), pp. 115 y 116; BASOZABAL (1998), pp. 268, 277 y 301.

119 DE CUPIS (1975), p. 97; BRIGUGLIO (1971), p. 175; BUSTO (1998), p. 383; TORREGROSSA (1964), p. 75; GIACOBBE (2005), p. 102; CÉSPEDES (2016), p. 333

${ }^{120}$ Teniendo la misma idea que evoca alguna de las acepciones de "compensar" según la RAE: 1. Igualar en opuesto sentido el efecto de una cosa con el de otra; 2. Dar algo o hacer un beneficio a alguien en resarcimiento del daño, perjuicio o disgusto que se ha causado.

${ }^{121}$ BARROS (2009), p. 28; PEÑAILILLO (1996), pp. 14 y 16.

122 DÍEZ-PICAZO (1966), pp. 846, 853 y 854; ALONSO (1983), pp. 257, 261 y 267; BASOZABAL (1998), pp. 268 y 277 y ss; CÉSPEDES (2016), p. 315.

123 BARROS (2020), p. 512.

124 MONTORY (2019), p. 118. En el mismo sentido, DÍEZ-PICAZO (1991), pp. 1269 y 1270.

125 PEÑAILILLO (1995), pp. 76 y ss. En el mismo sentido, Corte de Apelaciones de Concepción, Rol № 2462-2007, de 07 de agosto de 2009.
} 
En estos últimos casos, apreciamos que la "indemnización" que dispone la ley solo se extiende al daño patrimonial efectivamente causado y que es necesario para el ejercicio del derecho en cuestión ${ }^{126}$, no extendiéndose de ninguna forma ni a la reparación del daño extrapatrimonial ni del id quod interest ${ }^{127}$. El fundamento de ello lo encontramos en que tras estos daños lícitos lo que se persigue es restablecer el equilibrio patrimonial roto por la disposición normativa que autoriza el comportamiento dañoso, que entendemos como cumplido pagando el valor objetivo o de cambio del derecho o interés sacrificado o perturbado ${ }^{128}$.

Además, porque los daños a los que nos estamos refiriendo son aquellos calificados como daños lícitos o no antijurídicos, y la esencia de la prestación del id quod interest es "la causación de un perjuicio, del daño injusto, antijurídico, imputable objetivamente a la falta de cumplimiento, cuando, además, tal incumplimiento es subjetivamente imputable al deudor..."129. Así las cosas, atendido el fundamento mencionado, resulta coherente que el quantum de la reparación solo comprenda la aestimatio rei - total o parcialmente-pero nunca el id quod interest ${ }^{130}$, que es el interés que el perjudicado tenía en las cosas de que ha sido privado o perturbado o el valor que tengan precisamente para la persona perjudicada, o sea, la repercusión subjetiva en el patrimonio de la víctima (pretium singulare); a diferencia de la aestimatio rei, que se refiere al pretium commune o valor que el objeto tiene para todos ${ }^{131}$. De lo contrario, no habría diferencia de tratamiento entre los daños ilícitos de aquellos causados justamente por haberlos permitido el ordenamiento, lo que no resultaría lógico.

La fuente de la obligación de las reparaciones concedidas con motivo de la denominada "responsabilidad por hechos o actos lícitos"es la ley o el enriquecimiento sin causa

Este aserto es relevante para distinguir a esta clase de reparaciones de aquellas provenientes de la responsabilidad civil, que traen por causa a la existencia de un delito 0 cuasidelito civil o de un contrato, por medio de su incumplimiento.

En la generalidad de los casos su fuente de la obligación es la ley ${ }^{132}$, que, además de haber autorizado o permitido el comportamiento dañoso o perjudicial, ha determinado la existencia de una "indemnización" por aquel. Un jurista español lo graficaba con el siguiente brocardo: "se autoriza el daño, pero se le pone precio"133.

Ello obedece a la idea de que el legislador, al contemplar una "indemnización", lo que hizo fue demarcar el contenido del respectivo derecho, asignándole una consecuencia por los menoscabos o pérdidas causadas al patrimonio ajeno, como mecanismo de equilibrio de los

\footnotetext{
${ }^{126}$ Así lo ha reconocido la sentencia de la Corte de Apelaciones de Concepción, Rol № 946-2018, de 22 de marzo de 2019 , aunque en terminología de responsabilidad civil: “... la indemnización debe resarcir el valor del bien, reemplazándolo por otro de monto equivalente, con el objeto de evitar un menoscabo o perjuicio del patrimonio del propietario afectado, debiendo efectivamente, como lo indica la sentencia en alzada, indemnizarse los posibles perjuicios que se causen a quien debe soportar el deterioro de su dominio en razón de la actividad consustancial a tender tuberías y ocupar y cerrar los terrenos y realizar las obras requeridas para el transporte y la distribución del gas".

127 CÉSPEDES (2016), p. 322.

128 CÉSPEDES (2016), p. 322.

129 LLAMAS (2020), p. 263, que si bien se refiere a la relación contractual, pone de manifiesto la existencia de un hecho ilícito imputable al dañador como condición para la reparación de tales perjuicios, presupuesto que no concurre en los daños lícitos reparables, donde no existe una conducta reprochable del autor del daño ni tampoco criterio de imputación del mismo propio de la responsabilidad civil. En el mismo sentido, CÉSPEDES (2016), p. 315.

${ }^{130}$ Así, refiriéndose a las funciones de la indennità en el ordenamiento italiano, Messineo apunta lo siguiente: "Inoltre, l'indennità è correlativa a un danno, ma non anche a un atto illecito e, quindi, essa - a rigore- esula dalla materia dell'atto illecito; e - a quanto pare-l'indennità si risolve nella prestazione della sola aestimatio", MESSINEO (1958), p. 562. También, CÉSPEDES (2016), nota 1485, p. 325.

${ }^{131}$ LLAMAS (2010a), p. 3. Un completo y exhaustivo análisis puede verse en todo el desarrollo de la obra de LLAMAS (2020). En sentido similar, CÉSPEDES (2016), p. 314

${ }^{132}$ CORRAL (2013), p. 117; CÉSPEDES (2016), pp. 342 y ss.

${ }^{133}$ CAVANILLAS (1987), p. 147.
} 
intereses en juego ${ }^{134}$. Es decir, la indemnización dispuesta por la ley constituye una opción legislativa que, frente al sacrificio del derecho de uno de los titulares de los intereses en conflicto, estima como necesaria la distribución de las consecuencias negativas del evento dañoso o desventajoso, atendido que ambos intereses son dignos de protección para el ordenamiento jurídico. A través del mecanismo de la reparación, el titular del interés sacrificado no soporta exclusivamente los efectos adversos causados por el ejercicio del derecho considerado más digno de prevalecer por el ordenamiento, manifestándose de esta forma el carácter equitativo de este sistema de solución de conflictos jurídicos ${ }^{135}$.

Así las cosas, la regulación del conflicto de intereses que se presenta en esta clase de situaciones y el otorgamiento de la correspondiente indemnización es tarea propia del legislador ${ }^{136}$. Se ha sostenido que la solución de tales constituye un ejercicio previo a la convivencia social, resultando ser la norma jurídica el instrumento idóneo para eliminar tal controversia, sea disponiendo la preeminencia de un interés sobre otro, sea restringiendo el contenido de ambos para obtener la compatibilidad que permita una ordenada convivencia ${ }^{137}$. De allí que la doctrina que se ha ocupado del tema afirme que los casos estudiados "son supuestos expresamente contemplados por la ley"138.

Por lo demás, la consecuencia "indemnizatoria" se entiende solo por la existencia de la ley que la ha dispuesto, puesto que, de no haberla contemplado, ninguna compensación tendría derecho a percibir el dañado o afectado, ya que, como dijimos, habría operado la causal de justificación de ejercicio legítimo de un derecho (como se aprecia nítidamente en la retractación tempestiva de la oferta). Y bien sabemos, como regla general, que los daños justamente causados no se indemnizan ${ }^{139}$.

Asimismo, dado que nuestro sistema no contempla la existencia de una obligación "indemnizatoria" como consecuencia de los daños causados en estado de necesidad -como si acontece en otras latitudes $-{ }^{140}$, existe unanimidad en nuestra doctrina de la procedencia de tal compensación a través del principio del enriquecimiento injustificado ${ }^{141}$. Pese a no enunciarse formalmente como fuente de obligaciones, la jurisprudencia chilena lo reconoce y la doctrina chilena la enuncia como tal - como ya se dijo- , indicando que la existencia del enriquecimiento sin causa para obtener soluciones equitativas encuentra asidero legal en los artículos 578 y 1437 CC, al enunciar, respectivamente, al "hecho suyo" como fuente de derechos personales y al "hecho voluntario" como fuente de obligaciones, permitiendo amparar en su amplitud al "hecho" que provocó el enriquecimiento ${ }^{142}$. Asimismo, el fundamento equitativo antes indicado - corregir situaciones injustas ya consumadas - se puede obtener en virtud del principio de inexcusabilidad, conforme al cual los tribunales están obligados a solucionar la controversia sometida a su conocimiento aunque falte norma que resuelva el conflicto (art. 10 del Código Orgánico de Tribunales), debiendo en dicho caso recurrir a la equidad (art. $170 \mathrm{~N}^{\circ} 5$ del Código de Procedimiento Civil, sobre requisitos que deben cumplir las sentencias definitivas) ${ }^{143}$; y sin

\footnotetext{
${ }^{134}$ CÉSPEDES (2016), p. 353.

135 CÉSPEDES (2016), pp. 337 y ss.

${ }^{136}$ CÉSPEDES (2016), p. 353.

137 TORREGROSSA (1964), p. 74; CÉSPEDES (2016), pp. 353 y 354.

138 BUSTO (1998), p. 166. Es lo que DÍEZ-PICAZO refiere como "supuestos legalmente reglamentados", también conocidas por la doctrina tradicional como obligaciones que nacen directamente de la ley u obligaciones ex lege. Indica que comprende dos grupos: a) el que incluye a todas aquellas obligaciones que tienden a reparar o a restituir un equilibrio patrimonial roto como consecuencia de un acto lícito o de una atribución justificada, y; b) el constituido por aquellas obligaciones que nacen de un determinado estado o situación (Zustandobligationem), DÍEZ-PICAZO (2008), pp. 182 y 183. Véase CÉSPEDES (2016), pp. 352-354.

139 DíEZ-PICAZO (1979), p. 735.

140 Por ejemplo, arts. 2045 Código Civil italiano; 339 del Código Civil portugués; 118.1 Código Penal español; 1718 letra c) Código Civil y Comercial argentino.

${ }^{141}$ BARROS (2020), p. 146. En el mismo sentido, CORRAL (2013), p. 123; RODRÍGUEZ GREZ (1999), p. 157; AEDO (2006), pp. 269 y 270. En el Derecho comparado también se reconoce como fundamento al enriquecimiento sin causa, DÍEZ-PICAZO (1999), pp. 301 y 302; GARCÍA-RIPOLL (2006), p. 154

142 PEÑAILILLO (1996), pp. 7 y ss.

143 PEÑAILILLO (1996), p. 12
} 
perjuicio de que la equidad natural es una regla de interpretación de la ley que se aplica a falta de las reglas indicadas en los artículos 19 a 23 CC, conforme lo indica el artículo 24 CC $^{144}$.

Pues bien, la fuente de las reparaciones concedidas con motivo de la denominada "responsabilidad por hechos o actos lícitos" coincide con la de las indemnizaciones o compensaciones por sacrificio, puesto que normalmente traen como fuente la ley ${ }^{145}$, con la excepción en nuestro país de la compensación de los daños causados en estado de necesidad, que en otros ordenamientos se configura también como obligación legal; pero que obedece a la misma lógica descrita.

En consecuencia, las funciones de las compensaciones por sacrificio se cumplen en los supuestos de la denominada "responsabilidad por hecho o acto lícito"

Hemos destacado en los acápites anteriores que esta clase de indemnizaciones son completamente extrañas a la responsabilidad civil. Asimismo, las compensaciones económicas surgidas de la denominada "responsabilidad por hecho o acto lícito" limitan el quantum reparatorio, ya que solo tienen por objeto restituir, restaurar o reintegrar el valor del bien o interés sacrificado y que es necesario para el ejercicio del derecho en cuestión, o bien, restituir el enriquecimiento producido. Por otro lado, hemos corroborado que tal obligación trae como fuente normalmente a la ley, transformándose en un mecanismo de solución del conflicto de intereses, ya que el titular del interés sacrificado por la opción legislativa no soporta exclusivamente los efectos adversos causados por el ejercicio del derecho considerado más digno de prevalecer por el ordenamiento, manifestándose de esta forma su carácter equitativo.

Finalmente, también apreciamos que, en los supuestos estudiados, la existencia de una norma permisiva o autorizante confiere licitud a un acto objetivamente ilícito, como lo sería la apropiación, privación o destrucción de una cosa ajena o la agresión al patrimonio de un tercero ${ }^{146}$.

\section{Conclusiones}

1.- Los supuestos que se contemplan bajo la denominación de "responsabilidad por hecho o acto lícito" no constituyen manifestaciones de responsabilidad alguna, por lo que tal conceptualización conduce a equívocos.

2.- La indemnización que se contempla para tales casos traen por causa la existencia de daños lícitos o de restituciones de enriquecimientos, completamente ajenas al sistema de responsabilidad civil.

3.- Tales "indemnizaciones" participan de la naturaleza jurídica de las "compensaciones por sacrificio". En consecuencia, solo se compensan aquellos daños o pérdidas que son consustanciales al ejercicio del derecho que privilegia el ordenamiento mediante el pago del valor objetivo o de cambio del derecho o interés sacrificado o perturbado, dada la lógica restitutoria que se encuentra tras dichas reparaciones.

4.- Por lo anterior, parece conveniente cambiar la denominación de "responsabilidad por hecho o acto lícito" por la de "compensaciones por hechos o actuaciones ajustadas a Derecho" o calificarlas simplemente como supuestos de "compensaciones por sacrificio".

\section{BIBLIOGRAFÍA CITADA}

Abeliuk MANASEVICH, René (2014): Las obligaciones, 6a edición actualizada (Santiago, Thomson Reuters), tomo I.

\footnotetext{
${ }^{144}$ Sobre el tema, LETELIER (2018), pp. 649 y ss.

${ }^{145}$ CÉSPEDES (2016), pp. 344 y ss.

${ }^{146}$ CORRAL (2013), p. 117 indica otro fundamento, señalando que en estos casos “la ley condiciona la licitud de la actuación al pago de la indemnización".
} 
Aedo BARREnA, Cristian (2006): Responsabilidad extracontractual (Santiago, Librotecnia).

AlESSI, RenATo (1968): "La responsabilità da atti legittimi", en: Azara, Antonio y Eula, Ernesto (Dirs.), Novissimo Digesto Italiano (Turín, Utet), tomo XV, pp. 625-628

Alonso PÉrez, MARIANo (1980): “Arts. 353 y ss.", en: Albaladejo, Manuel (Dir.), Comentarios al Código Civil y Compilaciones Forales (Madrid, Edersa), tomo V, volumen 1, pp. 192-338.

BARNÉs, JAVIER (1995): "El Derecho de propiedad en la Constitución española de 1978", en: Barnés, Javier (Coord.), Propiedad, expropiación y responsabilidad (Madrid, Tecnos), pp. 25-66.

BARRIENTOS GRANDÓN, JaVIer (2017): “Enriquecimiento injustificado y codificación: modelos y decisiones dogmáticas (siglo XIX)", en: Del Olmo, Pedro y Basozabal, Xabier (Dirs.), Enriquecimiento injustificado en la encrucijada: historia, Derecho comparado y propuestas de modernización (Cizur Menor, Thomson Reuters-Aranzadi), pp. 49-119.

BARROS BoURIE, ENRIQUE (2009): “Restitución de ganancias por intromisión en derecho ajeno, por incumplimiento contractual y por ilícito extracontractual”, en: Barros, Enrique; García Rubio, María Paz y Morales Moreno, Antonio, Derecho de Daños (Madrid, Fundación Coloquio Jurídico Europeo), pp. 11-78.

(2020): Tratado de responsabilidad extracontractual, 2ª edición actualizada (Santiago, Editorial Jurídica de Chile), tomos I y II.

Basozabal Arrue, Xabier (1998): Enriquecimiento injustificado por intromisión (Madrid, Civitas).

BeNítez CAORSI, JUAN (2005): "El estado de necesidad en la responsabilidad civil", en: Revista Latinoamericana de Derecho (Año II, № 4), pp. 27-55.

BIANCA, C. MASSIMO (2019): Diritto Civile. V. Responsabilità, reimpresión actualizada de la 2a edición (Milán, Giuffrè Francis Lefebvre).

BONET RAMÓN, Francisco (1981): "Responsabilidad legal (estricta)", en: Revista General de Legislación y Jurisprudencia (noviembre, № 5), pp. 427-463.

BRIGUglio, MARCELlo (1971): El estado de necesidad en el Derecho Civil (Traducc. Manuel García Amigo, Madrid, Editorial Revista de Derecho Privado).

BRUN, PHILIPPE (2015): Responsabilidad civil extracontractual (Lima, Instituto Pacífico).

BuonaURo, CARLo (2012): Responsabilità da atto lecito dannoso (Milán, Giuffrè Editore).

BUSTO LAGO, JOSÉ MANUEL (1998): La antijuridicidad del daño resarcible en la responsabilidad civil extracontractual (Madrid, Tecnos).

CARRAsco PeRERA, Ángel (1986): lus aedificandi y accesión (Madrid, Editorial Montecorvo).

CAVANILlas MúgICA, SANTIAGO (1987): La transformación de la responsabilidad civil en la jurisprudencia (Pamplona, Editorial Aranzadi).

CÉSPEDES MUÑOZ, CARLoS (2016): El daño lícito (Madrid, La Ley-Wolters Kluwer).

(2018A): “¿Solo por ley nace la obligación indemnizatoria de Derecho público? Notas de la indemnización de Derecho público desde la perspectiva del ordenamiento español", en: Revista de Derecho U. Católica del Norte (Año 25, № 1), pp. 77-119.

(2018B): "El daño lícito reparable y su proyección en el sistema chileno: concepto y naturaleza”, en: Revista lus et Praxis (Año 24, № 1), pp. 129-158.

(2019): "Identificando a las indemnizaciones por sacrificio en el sistema chileno", en: Gómez, Maricruz; Hernández, Gabriel; Lathrop, Fabiola y Tapia, Mauricio (Eds.), Estudios de Derecho Civil XIV (Santiago, Thomson Reuters), pp. 1041-1055. 
CÉSPEDes Muñoz, CARlos y VARgas ARAVENA, DAVID (2008): "Acerca de la naturaleza jurídica de la compensación económica. La situación en Chile y en España", en: Revista Chilena de Derecho (Vol. 35, № 3), pp. 439-462.

CLARO SOLAR, LUIS (1979): Explicaciones de Derecho Civil y Comparado (Santiago, Editorial Jurídica de Chile), volumen V.

CORDERO VEGA, LUIS (2012): “Las vacas locas y la responsabilidad del Estado por acto lícito", en: El Mercurio Legal, 22 de noviembre de 2012. Disponible en: www.elmercurio.com [visitado el 16 de junio de 2015].

CORRAL TAlCIANI, HeRnáN (2007): "La compensación económica en el divorcio y la nulidad matrimonial”, en: Revista Chilena de Derecho (Vol. 34, № 1), pp. 23-40.

(2013): Lecciones de responsabilidad civil extracontractual, 2a edición actualizada (Santiago, Legal Publishing-Thomson Reuters).

(2018): "A ciencia y paciencia", en: Blog Derecho y Academia. Disponible en: https://bit.ly/3eziqFt [visitado el 10 de enero de 2019].

De Ángel YAGüEZ, RICARDo (1993): Tratado de responsabilidad civil (Madrid, Civitas).

DE CUPIS, ADRIANO (1975): El daño. Teoría general de la responsabilidad civil, 2a edición italiana (Traducc. Ángel Martínez Sarrión, Barcelona, Bosch).

DELL'ANDRO, RENATO (1958): “Antigiuridicità", en: V.V.A.A., Enciclopedia del Diritto (Milán, Giuffrè Editore), tomo II, pp. 542-559.

DíEZ-PICAZO, LUIS (1966): "La modificación de las relaciones jurídico-reales y la teoría de la accesión”, en: Revista Crítica de Derecho Inmobiliario (№ 455), pp. 829-862.

(1979): "La responsabilidad civil hoy", en: Anuario de Derecho Civil (Vol. 32, № 4), pp. 727-738.

(1991): "Algunas reflexiones sobre el derecho de propiedad privada en la Constitución", en: Martín-Retortillo, Sebastián (Coord.), Estudios sobre la Constitución Española. Homenaje al profesor Eduardo García de Enterría (Madrid, Civitas), tomo II, pp. 1257-1270.

(1999): Derecho de Daños (Madrid, Civitas).

(2008): Fundamentos del Derecho civil patrimonial. Las relaciones obligatorias, $6 \underline{a}$ edición (Cizur Menor, Thomson Civitas), volumen II.

Domínguez ÁGUILA, RAMÓN (2007): "La compensación económica en la nueva legislación de matrimonio civil”, en: Revista Actualidad Jurídica (№ 15), pp. 83-92.

ENECCERUS, LUDWIG (1950): Derecho Civil. Parte general, 2a edición al cuidado de José Puig Brutau (Traducc. Blas Pérez González y José Alguer, Barcelona, Bosch), volumen II.

FISCHER, HANS (1928): Los daños civiles y su reparación (Traducc. Wenceslao Roces, Madrid, Revista de Derecho Privado).

FLeINER, FRITZ (1933): Instituciones de Derecho administrativo, 8a edición alemana (Traducc. Sabino A. Gendin, Barcelona-Madrid-Buenos Aires, Editorial Labor S.A.).

FORSTHOFF, ERNST (1958): Tratado de Derecho administrativo (Madrid, Instituto de Estudios Políticos).

García De EnTERRía, EduARdo (1984): Los principios de la nueva ley de expropiación forzosa, reedición (Madrid, Civitas).

García De Enterría, EduARdo y Fernández, Tomás (2017): Curso de Derecho Administrativo, 15ạ edición (Cizur Menor, Civitas-Thomson Reuters), tomo II. 
García-Ripoll MontiJano, Martín (2006): llicitud, culpa y estado de necesidad. Un estudio de responsabilidad extracontractual en los Códigos Penal y Civil (Madrid, Dykinson).

GarRido Falla, Fernando (1952): "La teoría de la indemnización en Derecho público", en: V.V.A.A., Estudios dedicados al profesor Gascón y Marín (Madrid, Instituto de Estudios de Administración Local), pp. 411-443.

(1988): Tratado de Derecho Administrativo, 8a edición (Madrid, Tecnos), volumen

II.

GHeRSI, CARLOS (1997): "Responsabilidad por actos lícitos", en: Bueres, Alberto y Kemelmajer, Aída (Dirs.), Responsabilidad por daños en el tercer milenio (Buenos Aires, Abeledo Perrot), pp. 474-480.

GIACOBBE, GIOVANNI (2005): "Gli atti leciti dannosi nella teoria della responsabilità civile", en: Mario Bessone (Dir.), Trattato di diritto privato. Illecito e responsabilità civile (Turín, Giappichelli Editore), volumen X, pp. 100-104.

GIORGI, GIORGIO (1911): Teoría de las obligaciones (Traducc. Eduardo Dato Iradier, Madrid, Hijos de Reus Editores), volumen V.

GonzÁlez PÉREZ, Jesús (2016): Responsabilidad patrimonial de las Administraciones Públicas, 8a edición (Cizur Menor, Civitas-Thomson Reuters).

GORDLEY, JAMES Y TALOR, ARTHUR (2006): An introduction to the comparative study of Private Law: reading, cases, materials (Cambridge, Cambridge University Press).

GUALANDI, ANGELO (1962): Spese e danni nel processo civile (Milán, Giuffrè Editore).

HARRIS, PEDRO (2019): "35 aniversario de la SCS Galletué (1984), sobre la responsabilidad por acto lícito: ¿réquiem o resurrección?", en: El Mercurio Legal, 29 de octubre de 2019, 1-3. Disponible en: www.elmercurio.com [visitado el 30 de octubre de 2019].

KAHL, WolfGANG (1995): "La conservación del medio ambiente y el derecho de propiedad en Alemania", en: Javier Barnés (Coord.), Propiedad, expropiación y responsabilidad (Madrid, Tecnos), pp. 755-788.

KARILA DE VAN, JULIANA (1995): “Le droit de nuire”, en: RTDC (julio-septiembre), pp. 533-558.

KIMMINICH, OTTO (1995): "La propiedad en la Constitución alemana”, en: Javier Barnés (Coord.), Propiedad, expropiación y responsabilidad (Madrid, Tecnos), pp. 151-174.

KRAUSE MUÑOZ, MARÍA SOlEDAD (2015): Responsabilidad: lo unitario en los sistemas civil y penal (Santiago, Thomson Reuters).

LaRENZ, KARL (1959): Derecho de Obligaciones (Traducc. Jaime Santos Briz, Madrid, Editorial Revista de Derecho Privado).

Lehmann, HeinRICH (1956): Tratado de Derecho Civil. Parte general. I. (Traducc. José M. Navas, Madrid, Editorial Revista de Derecho Privado).

LeÓN HURTADO, Avelino (1991): La voluntad y la capacidad en los actos jurídicos, 4a edición actualizada (Santiago, Editorial Jurídica de Chile).

Letelier Cibié, PABLo (2018): “Enriquecimiento injustificado y equidad. Los problemas que plantea la aplicación de un principio general”, en: Revista lus et Praxis (Año 24, № 2), pp. 649-670.

LLAMAS Pombo, EUGENIO (2010A): “Formas de reparación del daño (I)", en: Práctica de Derecho de Daños (№ 80), La Ley 183/2010. Disponible en: www.laleydigital.es [visitado el 01 de junio de 2012]. 
(2010B): Reflexiones sobre derecho de daños: casos y opiniones (Madrid, La LeyWolters Kluwer).

(2020): Cumplimiento por equivalente y resarcimiento del daño al acreedor. Entre la aestimatio rei y el id quod interest, nueva edición (Madrid, La Ley-Wolters Kluwer).

LóPez MeSA, MARCELo (2019): La responsabilidad civil (Montevideo - Buenos Aires, Editorial B de F).

MARKESINIS, BASIL; BelL, JOHn y JANSSEN, ANDRÉ (2019): Markesinis's German Law of Torts, 5a edición (Oxford, Hart).

MAzzola, MARCELlo (2007): Responsabilità civile da atti leciti dannosi (Milán, Giuffrè Editore).

MenÉndez Sebastián, Eva (2013): "Principios de la responsabilidad extracontractual de la Administración Pública (arts. 139 y 141 LRJPAC)", en: Quintana López, Tomás (Dir.), La responsabilidad patrimonial de la Administración Pública, 2ª edición (Valencia, Tirant lo Blanch), volumen I, pp. 37-90.

Messineo, Francesco (1958): Manuale di Diritto Civile e Commerciale (Codici e norme complementari), 9a edición (Milán, Giuffrè Editore), tomo V.

Montory BARRIGA, GonZAlo (2019): La propiedad constitucional: limitaciones, privaciones, contenido esencial (Valencia, Tirant lo Blanch).

MIR PUIGPELAT, ORIOL (2002): La responsabilidad patrimonial de la Administración. Hacia un nuevo sistema (Madrid, Civitas).

MontT RetTIG, PAULo (2017): “Responsabilidad del Estado por actos lícitos: ¿queda espacio para reclamar perjuicios por privaciones o limitaciones de dominio?", en: Schopf Olea, Adrián y Marín González, Juan Carlos (Eds.), Lo público y lo privado en el Derecho. Estudios en homenaje al profesor Enrique Barros Bourie (Santiago, Thomson Reuters), pp. 839-861.

Morozzo Della Rocca, Paolo (1998): "Gli atti leciti dannosi", en: Cendon, Paolo (Dir.), Responsabilità civile. Responsabilità Extracontrattuale (Turín, Utet), tomo VIII, pp. 413-444.

Pantaleón Prieto, Fernando (1987): “Art. 612", en: Albaladejo, Manuel (Dir.), Comentarios al Código Civil y compilaciones forales (Madrid, Edersa), tomo VIII, volumen 1, pp. 311-336.

(1991): “Art. 1902", en: Paz-Ares, Cándido; Díez-Picazo, Luis; Bercovitz, Rodrigo y Salvador, Pablo (Dirs.), Comentario del Código Civil (Madrid, Centro de Publicaciones Ministerio de Justicia), tomo II, pp. 1971-2003.

(1994): "Los anteojos del civilista: hacia una revisión del régimen de responsabilidad patrimonial de las Administraciones públicas", en: Documentación Administrativa (№ 237-238), pp. 239-253.

(1995): “Indemnización (Derecho Civil)”, en: AA.VV., Enciclopedia jurídica básica (Madrid, Civitas), tomo II, pp. 3517-3520.

(Madrid, Civitas).

(1996): La responsabilidad civil de los auditores: extensión, limitación y prescripción

Peñallillo Arévalo, Daniel (1995): La expropiación ante el Derecho Civil, 2a edición (Santiago, Editorial Jurídica de Chile).

(1996): "El enriquecimiento sin causa. Principio de Derecho y fuente de obligaciones", en: Revista de Derecho U. de Concepción (№ 200), pp. 7-40.

(2019): Los bienes. La propiedad y otros derechos reales, 2ª edición (Santiago, Thomson Reuters). 
Perlingieri, Pietro (1980): Codice civile annotato con la dottrina e la giurisprudenza (Torino, Utet), libro quinto.

(2004): "La responsabilità civile tra indennizzo e risarcimento", en: Rassegna di diritto civile (№ 4), pp. 1061-1088.

Pino EMHART, AlBerto (2019): "Los supuestos de restitución de ganancias ilícitas en el Derecho Privado Chileno", en: Revista Chilena de Derecho (Vol. 46, № 2), pp. 373-398.

Pinochet Olave, Ruperto y Concha MachucA, Ricardo (2015): "Las prestaciones mutuas en caso de nulidad de contrato: carácter indemnizatorio o restitutorio en el Derecho civil chileno", en: Revista de Derecho Privado (№ 28), pp. 129-152.

Reglero Campos, Fernando y Peña López, Fernando (2013): “Conceptos generales y elementos de delimitación", en: Busto Lago, José Manuel y Reglero Campos, Fernando (Coords.), Lecciones de responsabilidad civil, 2ª edición (Cizur Menor, Thomson Reuters Aranzadi), pp. 41-62.

(2014): "Conceptos generales y elementos de delimitación", en: Reglero Campos, Fernando y Busto Lago, José Manuel (Coords.), Tratado de responsabilidad civil, 5 a edición (Cizur Menor, Thomson Reuters Aranzadi), tomo I, pp. 66-263.

ROdRÍGUEZ GREZ, PABLO (1999): Responsabilidad extracontractual (Santiago, Editorial Jurídica de Chile).

Rosende Álvarez, Hugo (1979): Responsabilidad precontractual (Valparaíso, Ediciones Universitarias de Valparaíso).

RUIZ ARRANZ, ANTONIO (2018): "La oferta de contrato: vinculación y responsabilidad", en: Anuario de Derecho Civil (tomo LXXI-4), pp. 1351-1486.

SANZ EnCINAR, AbRAHAM (2001): "El concepto jurídico de responsabilidad en la teoría general del Derecho", en: Pantaleón, Fernando (Ed.), La responsabilidad ante el Derecho (Madrid, U. Autónoma de Madrid-Boletín Oficial del Estado), pp. 27-55.

SCOTTI, ElISA (2014): "Responsabilità da atto lecito e principio di compensazione", en: lus Publicum, octubre. Disponible en: www.ius-publicum.com [visitado el 27 de noviembre de 2019].

TARDío PATO, JOSÉ ANTONIO (2000): Expropiación forzosa y acciones civiles (Pamplona, Aranzadi).

TORREGROSSA, GIOVANNI (1964): II problema della responsabilità da atto lecito (Milán, Giuffrè Editore).

TRIMARCHI, PIETRO (1961): Rischio e responsabilità oggettiva (Milán, Giuffrè).

TUCCI, GIUSEPPE (1967): “La risarcibilitá del danno da atto lecito nel diritto civile”, en: Riv. Dir. Civ. (Año XIII, parte prima), pp. 217-268.

VIDAL Olivares, ÁlVARO (2004): “La compensación económica en la Ley de Matrimonio Civil: un nuevo régimen de responsabilidad civil extracontractual", en: Revista de Derecho de la U. de Concepción (№ 213-214), pp. 265-287.

VINEY, GeneVIÈVe y Jourdain, PATRICE (2013): "Les conditions de la responsabilitè", en: Ghestin, Jacques (Dir.), Traitè de Droit Civil, 4a edición (París, LGDJ).

VISINTINI, GIOVANNA (1999): Tratado de la responsabilidad civil. 1. La culpa como criterio de imputación de la responsabilidad (Traducc. Aída Kemelmajer de Carlucci, Buenos Aires, Editorial Astrea).

WILENMANN Von BÉRnAtH, JAVIER (2017): "Concepto de responsabilidad y estructura de los modelos de imputación", en: Schopf Olea, Adrián y Marín González, Juan Carlos (Eds.), Lo público 
y lo privado en el Derecho. Estudios en homenaje al profesor Enrique Barros Bourie (Santiago, Thomson Reuters), pp. 263-297.

YZQUiERdo Tolsada, MARIANo (2001): Sistema de responsabilidad civil, contractual y extracontractual (Madrid, Dykinson).

(2015): Responsabilidad civil extracontractual (Madrid, Dykinson).

JURISPRUDENCIA CITADA

ComunidAd GalletuÉ CON Fisco De ChILE (1984): Corte Suprema 07 agosto 1984 (indemnización de perjuicios), Rol № 16.743-1983, en: www.westlawchile.cl, CL/JUR/2/1984.

Sociedad Agrícola Lolco LtdA. con Fisco de CHILe (2004): Corte Suprema 30 de diciembre 2004 (indemnización de perjuicios), Rol № 381-2004, en: www.pjud.cl.

FISCO DE CHILE CON IngenIeRía y CONSTRucCIÓn SAN ANDRÉs (2009): Corte Apelaciones Concepción 07 agosto 2009 (reclamación expropiación), Rol № 2462-2007, en: www.pjud.cl.

Productos Fernández S.A. con Ministerio de SALUd (2012): Corte Suprema 20 noviembre 2012 (indemnización de perjuicios), Rol № 9924-2010, en: www.pjud.cl.

Constructora Valko con Fisco de Chile (2017): Corte Suprema 03 enero 2017 (juicio de hacienda), Rol № 32.990-2016, en www.pjud.cl.

Guerrero con Serviu X Región (2018): Corte Suprema 03 septiembre 2018 (indemnización de perjuicios), Rol № 44.324-2017, en www.pjud.cl.

MuÑOZ CON SERVIU X Región (2018): Corte Suprema 17 diciembre 2018 (indemnización de perjuicios), Rol № 38.887-2017, en www.pjud.cl.

OctOPUS LNG SPA CON MADESAL (2019): Corte Apelaciones Concepción 22 marzo 2019 (servidumbres legales), Rol № 946-2018, en: www.pjud.cl. 